\title{
Review Article \\ Wild Edible Plant Nutritional Contribution and Consumer Perception in Ethiopia
}

\author{
Haile Tesfaye Duguma (iD) \\ Department of Postharvest Management, College of Agriculture and Veterinary Medicine, Jimma University, Ethiopia \\ Correspondence should be addressed to Haile Tesfaye Duguma; hailetesfaye840@gmail.com
}

Received 13 November 2019; Revised 7 August 2020; Accepted 14 August 2020; Published 4 September 2020

Academic Editor: Amarat (Amy) Simonne

Copyright $\odot 2020$ Haile Tesfaye Duguma. This is an open access article distributed under the Creative Commons Attribution License, which permits unrestricted use, distribution, and reproduction in any medium, provided the original work is properly cited.

\begin{abstract}
The scarcity, high cost, and unreliable supply of healthy food in developing countries have resulted in the search for cheap and alternative sources of healthy and nutritious food. Wild edible plants (WEPs) are one of the alternative sources of healthy and nutritious food, and they are crucially important in supporting the global food basket in all parts of the world in general and in sub-Saharan Africa in particular. These wild edible plants have played a significant role in supplying food and nutritional requirements and increasing the health status of poor communities in many rural parts of the world. In Ethiopia, rural communities use wild edible plants as a means of survival especially during times of drought and famine and during other forms calamities and crises. Wild edible plants have high nutritional content, including proteins, vitamin B2, and vitamin C, which can be used as alternatives to conventional plant-based human diets. The available literature has revealed that some wild edible plants also have medicinal properties. Even though wild edible plants are important for food security, they are usually overlooked and perceived as food for poor families. This review indicates that fruits are the most commonly used WEPs, both for consumption and medicinal value, and most plant parts are eaten directly in raw forms. This review focuses on the commercial exploitation of wild edible plants as a source of dietary supplements and alternative medicines and as a means to generate income; it also focuses on consumer perception toward wild edible plants in Ethiopia. Despite easy accessibility and availability, the consumption of wild edible plants is challenged by numerous factors. This review suggests that nutrition policies have to promote the utilization of wild edible plants as one pillar of food and nutrition security. Bioactive compound contents and antinutritional factor contents of wild and medicinal plants need further investigation.
\end{abstract}

\section{Introduction}

Food and nutrition security is a major challenge that our world is facing nowadays. Approximately two billion people are estimated to suffer from micronutrient deficiencies that make them more susceptible to disease, and this can be a significant obstacle to economic growth [1]. The issue of food security is severe, especially in largely import-dependent countries of sub-Saharan Africa [2]. However, the continent shows highly biodiverse environments with valuable, wild edible plants (WEPs) which are often neglected [3].

The long history of humans' ability to adapt to natural environments and to interact with nature and social circumstances is profoundly devoted to edible wild plants and animals. From the early hunter-gatherers and across different adaptation stages, plants have assumed great importance in human societies and many people all over the world have depended on many wild species particularly for food and medicines (Ferreira et al., 2016).

Wild edible plants are those plants with edible parts that grow naturally on farm land and on fallow or uncultivated land [4-6]. Different wild edible plants have played a significant role in different geographical regions of the world throughout human history [7].

Wild vegetables contribute to people's food security and health in many rural areas of the world $[8,9]$. They may have remarkable nutrient values and can be an important source of vitamins, fibers, minerals, and fatty acids; they may also 
show important medicinal properties [10]. Wild edible plants have always been an essential and widespread food source for food-insecure families living in poverty in developing countries $[11,12]$. They are relevant to household food security and nutrition in some rural areas and are relied on to supplement the staple food, to fill seasonal food shortages, and to serve as emergency food during famine [13-17]. They are also important for many communities in rural villages [18, 19] and even those in urban areas, especially among the poor and marginalized [20-22]. Wild edible plants are of crucial importance in all parts of the world in supporting the global food basket [23]. According to Lulekal et al. [24], about one billion people in the world use wild foods (mostly from plants) on a daily basis. Wild edible plants are nutritionally rich and can especially supplement vitamins and micronutrients [25]. They can also supplement nutritional requirements due to their better nutritional value [26, 27].

Besides nutritional value, income and employment can be obtained from the sale or exchange of their fruits, leaves, juice, and local drinks [5]. Although many wild edible plants are used as a food supplement or as a means of survival during drought and famine, the importance of wild edible plants has been overlooked by the majority of the rural population $[5,6,16,28]$.

Ethiopia is the fifth country in tropical Africa in terms of the diversity of flora [29]. In addition, it is known worldwide as one of the global centres of biodiversity where much of this biodiversity is associated with forest resources [30]. The Ethiopian flora contains approximately 6000 species of higher plants of which about $10 \%$ are endemic [29]. Ethiopia is known as the biodiversity hotspot and centre of origin and diversification for a significant number of food plants and their wild relatives (Awas, 1997). The wide range of climatic and edaphic conditions permitted the growth of a variety of wild edible plants [31].

Ethiopia is one of the developing countries which depend on wild edible plants to fulfil nutritional needs in addition to domesticated cultivars, especially in poor rural communities during periods of food scarcity $[32,33]$.

In most parts of Ethiopia, wild edible plants are a recovering part of the feeding habits of many communities [33]. Lulekal et al. [24] noted that about 413 kinds of WEPs are consumed in Ethiopia. Thus, many rural people of Ethiopia usually feed on wild edible plants for survival during food shortages [18]. The findings of this study conducted in Yayo forest show that indigenous fruits, vegetables, and tubers can make a positive contribution to food and nutrition security, as they are well adapted to local environmental conditions. Increasing the production of these underutilized food plants in farmers' home gardens and promoting their consumption could contribute to a more sustainable approach to prevent protein/energy malnutrition and micronutrient deficiencies [34]. Wild vegetables can constitute important local commodities fetching high prices on local and regional markets and as such contribute to local cash income $[35,36]$.

Wild plants provide medicines that are affordable and readily available to the vast majority of the rural population in Ethiopia, as is the case in many other developing countries in the world. Research has shown that many of the wild edible plants have been found to be rich sources of one or more of the nutritionally important substances, such as proteins, carbohydrates, vitamins, and minerals. Besides the dietary substances, some of them also contain considerable amounts of a variety of health-promoting compounds, such as phenolic compounds [37-39].

The food and nutritional contribution and the medicinal value of wild edible plants have not been investigated fully in Ethiopia. Therefore, the objective of this review is to explore available information about wild edible plants' nutritional contribution, supplementary role, marketability, and medicinal value, as well as to determine consumer perception toward wild edible plants in Ethiopia.

\section{Material and Methods}

The materials for this review were published documents. The author has included all information on WEPs of Ethiopia from well-known sources such as Scopus, Google Scholar, Web of Science, and Mendeley. Data on Ethiopian WEPs such as their scientific names, nutrition and medicinal values, supplementary role, and consumer perception were gathered and compiled after assessing all available Ethiopian ethnobotanical documents. The literature search also addressed WEPs from other countries in order to point out useful research practices that could be used for future ethnobotanical research on WEPs of Ethiopia. After collecting different scientific sources according to different criteria based on topic and academic field, a final inventory of 105 articles was reviewed thoroughly and provided in the reference list. The data obtained is critically reviewed and arranged systematically with reference to their uses. An Excel spreadsheet was used to analyze data using descriptive statistics to identify the number and percentage of commonly utilized plant parts, mode of consumption, marketability, and medicinal value of WEPs.

\section{Contribution of Wild Edible Plants to Food and Nutrition Security in Ethiopia}

Strategies for ensuring food security often advocate for an intensified agriculture that focuses on the enhanced production of major cereals only $[1,40]$, but the remaining portion of the agricultural sector is quite blind to dietary diversity, thus disrupting healthy food systems [41]. While there is a consensus that wild foods cannot entirely erase the gap between supply and demand, the researchers underline that the difference between supply and demand would be much wider if wild food was absent from our food system [42].

Underutilized edible wild fruits have become a very important part of human nutrition and cannot be overlooked as far as food security, good health, and income generation are concerned $[43,44]$. Proximate analysis of some wild edible plants demonstrates that, in many cases, their nutritional quality is comparable to and may be superior to domesticated varieties $[31,33]$. Wild edible plants are important nutrient and vitamin supplements for indigenous people [45, 46]. From the nutritional perspective, wild edible plants are sources of many micronutrients commonly lacking in 
staple-dependent diets in developing countries, which are important for human health and development [47]. Wild edible plants have high nutritional contents such as protein, vitamin B2, and vitamin $\mathrm{C}$, which are used as alternatives to conventional vegetables in the human diet [18].

Tables 1 and 2 indicate the proximate composition and mineral contents of some wild edible plants, respectively; the nutritional value recorded indicate that wild edible plants contain remarkable amounts of nutrients which can meet the recommended daily allowance. According to many sources, the amounts of vitamins, minerals, and other nutrients in wild food is on the average greater than in cultivated foods [48]. Wild fruits have great potential as sources of vital nutrients especially for growing children who are prone to malnutrition and who are key fruit collectors [18]. WEPs are consumed to supplement the nutrition of staple foods which is the solution to hidden hunger (hunger due lack of a balanced diet) [49]. To improve food and nutrition security, focusing on different dimensions of food sources like wild edible food is very crucial.

3.1. Supplementary Role of Wild Edible Plants. Wild edible plants are consumed for supplementing staple foods and filling food gaps (drought and famine). A study conducted by Tebkew et al. [50] at Quara District, northwest Ethiopia, indicated that wild edible plants were consumed to supplement staple foods (about 70\%) and fill food gaps (drought and famine, about 35\%). Wild edible plants (WEPs) provide staple food for indigenous people, serve as complementary food for nonindigenous people, and offer an alternative source of cash income for poor communities [51]. The selection of these edible plants is based on simplicity of processing, good taste, time of availability, and low labour requirement. The general public consumes most of the WEPs as snacks, supplements, or refreshments. Amente [52] indicated that most of the indigenous people of Gumuz People in Kamash Woreda occasionally consider WEPs as famine foods or foods in conditions of starvation. Among the wild edible plants in the study site, around $73.33 \%$ were used as supplementary food, while the rest $(26.67 \%)$ were used as regular food or as meals.

Wild edible plants are relevant to household food security and nutrition in some rural areas, particularly in dry lands, to supplement the staple food, to fill seasonal food shortages, and as emergency food during famine [13, 1517]. Assefa and Abebe [32] reported that out of 30 identified wild edible tree and shrub species, 15 (50\%) are used to supplement the regular food supply. Generally, the literature indicates that wild edible plants are used to supplement regular food.

Studies conducted by Maundu et al. [53] indicated that wild edible plants mostly serve as supplementary foods in different parts of Africa. In many parts of developing countries like Ethiopia, hundreds of wild edible plants are known to be sporadically consumed by rural communities [54]. In Ethiopia, wild edible plants are used as supplementary, seasonal, or survival food sources in many cultural groups, and hence plays a role in combating food insecurity [24]. Wild edible plants provide irreplaceable nutritional contents and economic values to people who depend on them in different parties of Ethiopia [55]. The role of wild edible plants as a supplement to nutritional requirements and as a coping strategy for food shortages is clearly indicated by different scholars $[16,32,33]$.

3.2. Wild Edible Plants Used as Traditional Medicine. In many countries, medicinal plants are widely used as dietary supplements, as daily foods, and as functional foods, with the aim of promoting health. Wild plants contain a large spectrum of plant secondary metabolic products such as polyphenols, terpenoids, and polysaccharides, which make them good candidates as nutraceuticals, i.e., functional foods which contain potentially health-promoting ingredients [56].

Globally, about $64 \%$ of the total world population are reliant on traditional medicine for their healthcare needs [57]. Traditional medicine is the sum total of all knowledge and practices used in diagnosis, prevention, and elimination of health problems and relying exclusively on practical experience and observation passed from generation to generation verbally and in writing [58]. The healing properties of plants have been developed through time by the trial and error experimentation of primitive men and women who struggled with the health problems they encountered, such as the miseries of pain, sickness, and sustained injuries [59].

It is known that many countries in Africa, Asia, and Latin America use traditional medicine (TM) to meet some of their primary health care needs [60]. More than 20,000 plant species are being used in various human cultures around the world for medicinal purposes [61]. Wild fruits have a curing ability for multiple disorders, such as diabetes, cardiovascular problems, inflammations, and digestive and urinary tract disorders, due to their rich sources of antioxidant and fiber components $[62,63]$.

About $85 \%$ of the population in the underdeveloped world do not have access to modern western style health care services (World Health Report, 2008) and rely on traditional medical systems for their health care [64]. Similar results were reported in different countries: a study conducted in Lebanon showed that wild foods were perceived to cure most diseases of human beings [65].

In Ethiopia, about $80 \%$ of the human population and $90 \%$ of livestock rely on traditional medicine $[66,67]$. There are 6000 species of higher plants in Ethiopia out of which more than $14 \%$ is used as traditional medicines [68]. Bekele [66] stated that 1000 identified medicinal plant species are reported in the Ethiopian flora. Out of the total wild edible plants found in Berehet District, North Shewa Zone of Amhara Region (Ethiopia), fourteen (23\%) nutraceutical wild plants were used to treat 10 (71\%) human and 4 (29\%) livestock primary health care problems. Asparagus africanus, Carissa spinarum, Cordia africana, and Ximenia americana are the most commonly used nutraceutical plants as well as edible plants reported by local people in the Amhara Region, Ethiopia [69]. From the wild edible plants used as traditional medicine, 7 shrubs (50\%), 3 herbs (21\%), and 4 trees (29\%) were the dominant growth forms of the wild edible plants used as traditional medicine in the area. Out of the total nutraceutical plants, leaves (40\%) were the most widely used 
TABle 1: Proximate composition (g/100 g) of some selected wild edible plants.

\begin{tabular}{|c|c|c|c|c|c|c|c|c|}
\hline Scientific name & $\begin{array}{l}\text { Moisture } \\
\text { (fw) }\end{array}$ & $\begin{array}{l}\text { Ash } \\
(\mathrm{dmb})\end{array}$ & $\begin{array}{c}\text { Ether extractives } \\
(\mathrm{dmb})\end{array}$ & $\begin{array}{c}\text { Protein } \\
(\mathrm{dmb})\end{array}$ & $\begin{array}{l}\text { Crude fiber } \\
(\mathrm{dmb})\end{array}$ & $\begin{array}{c}\mathrm{CH} \\
(\mathrm{dmb})\end{array}$ & $\begin{array}{c}\text { Energy } \\
(\mathrm{kcal}, \mathrm{dmb})\end{array}$ & References \\
\hline Dobera glabra $^{\mathrm{b}}$ & 28.10 & 6.79 & 0.46 & 16.00 & 2.41 & 48.65 & 253.10 & [95] \\
\hline Adenia ellenbeckii & $83.6 \pm 0.3$ & $13.8 \pm 0.1$ & $5.0 \pm 0.1$ & $27.7 \pm 0.2$ & $10.0 \pm 0.6$ & 43.5 & 174.1 & \\
\hline Amaranthus graecizans & $72.7 \pm 0.3$ & $22.0 \pm 0.1$ & $3.9 \pm 0.4$ & $28.5 \pm 0.2$ & $8.5 \pm 0.8$ & 37.1 & 148.2 & \\
\hline Balanites aegyptiaca & $63.5 \pm 1.2$ & $12.5 \pm 0.1$ & $2.5 \pm 0.8$ & $28.8 \pm 0.4$ & $15.5 \pm 0.3$ & 40.7 & 162.6 & \\
\hline Celosia argentea & $84.1 \pm 0.3$ & $23.9 \pm 0.5$ & $2.9 \pm 0.8$ & $32.7 \pm 0.1$ & $9.8 \pm 0.1$ & 30.7 & 122.9 & \\
\hline Coccinia grandis & $78.5 \pm 0.7$ & $15.2 \pm 0.1$ & $3.5 \pm 0.1$ & $36.3 \pm 0.2$ & $10.1 \pm 0.6$ & 34.9 & 139.6 & \\
\hline Corchorus trilocularis & $83.9 \pm 0.0$ & $15.4 \pm 0.8$ & $1.5 \pm 0.3$ & $20.4 \pm 0.2$ & $11.1 \pm 0.9$ & 51.7 & 206.8 & \\
\hline Justicia flava & $80.6 \pm 1.8$ & $25.6 \pm 0.0$ & $2.7 \pm 0.4$ & $32.9 \pm 0.5$ & $7.5 \pm 0.7$ & 31.3 & 125.4 & \\
\hline Justicia ladanoides & $73.4 \pm 0.5$ & $25.3 \pm 0.3$ & $2.9 \pm 0.3$ & $25.4 \pm 0.4$ & $12.5 \pm 0.5$ & 33.9 & 135.5 & \\
\hline Launaea intybacea & $80.1 \pm 1.3$ & $21.4 \pm 0.3$ & $3.7 \pm 0.1$ & $24.1 \pm 0.2$ & $10.7 \pm 0.1$ & 40.1 & 160.3 & \\
\hline Leptadenia hastata & $76.9 \pm 1.6$ & $13.8 \pm 0.2$ & $5.5 \pm 0.1$ & $20.3 \pm 0.8$ & $14.9 \pm 0.2$ & 45.5 & 182.0 & {$[54]$} \\
\hline $\begin{array}{l}\text { Pachycymbium } \\
\text { laticoronum }\end{array}$ & $90.5 \pm 0.8$ & $13.2 \pm 0.2$ & $3.1 \pm 0.5$ & $8.1 \pm 0.4$ & $15.1 \pm 0.2$ & 60.5 & 242.1 & \\
\hline Pentarrhinum insipidum & $77.0 \pm 0.8$ & $15.5 \pm 0.6$ & $3.3 \pm 0.1$ & $32.3 \pm 0.2$ & $10.9 \pm 0.2$ & 38.0 & 151.9 & \\
\hline Portulaca quadrifida & $90.9 \pm 0.5$ & $24.6 \pm 0.8$ & $3.1 \pm 0.2$ & $19.6 \pm 0.1$ & $15.9 \pm 0.2$ & 36.8 & 147.3 & \\
\hline $\begin{array}{l}\text { Amorphophallus } \\
\text { gomboczianus }^{\mathrm{a}}\end{array}$ & $84.5 \pm 0.4$ & $6.0 \pm 0.2$ & $0.4 \pm 0.1$ & $5.8 \pm 0.1$ & $4.3 \pm 0.0$ & 83.5 & 333.8 & \\
\hline Ximenia caffra ${ }^{\mathrm{b}}$ & $61.2 \pm 0.6$ & $5.0 \pm 0.2$ & $23.6 \pm 1.0$ & $21.6 \pm 0.1$ & $10.4 \pm 1.4$ & 39.4 & 157.5 & \\
\hline Coccinia grandis & $87.3 \pm 0.5$ & $15.9 \pm 0.2$ & $5.2 \pm 0.2$ & $28.7 \pm 0.4$ & $\mathrm{ND}$ & $\mathrm{ND}$ & ND & \\
\hline $\begin{array}{l}\text { Trigonella foenum- } \\
\text { graecum }\end{array}$ & $89.8 \pm 1.1$ & $23.8 \pm 0.4$ & $5.8 \pm 0.3$ & $28.0 \pm 0.7$ & ND & ND & ND & \\
\hline
\end{tabular}

All are green vegetables, unless otherwise mentioned; ${ }^{a}$ tuber; ${ }^{\mathrm{b}}$ fruit. $\mathrm{ND}=$ not determined; $\mathrm{CH}=$ carbohydrate.

TABLe 2: Mineral contents (mg/100 g dry weight bases) of selected wild edible plants.

\begin{tabular}{|c|c|c|c|c|c|c|c|}
\hline Scientific name & $\mathrm{Ca}$ & $\mathrm{Cu}$ & $\mathrm{Fe}$ & $\mathrm{Mg}$ & $\mathrm{Mn}$ & $\mathrm{Zn}$ & References \\
\hline Ziziphus spina-christi & $339.5+53.5$ & $1.18+0.23$ & $71.99+7.85$ & $76.3+2.3$ & ND & $2.7 \pm 0.4$ & {$[96]$} \\
\hline Moringa stenopetala & $792.8 \pm 92$ & $3.08 \pm 0.8$ & $2.89+2.2$ & ND & ND & $0.53 \pm 0.8$ & {$[97]$} \\
\hline Adenia ellenbeckii & 1239 & 0.54 & 16.6 & 404 & 7.8 & 3.1 & \\
\hline Amaranthus graecizans & 3029 & 0.65 & 19.3 & 2049 & 7.2 & 2.3 & \\
\hline Balanites aegyptiaca & 2487 & 0.61 & 13.5 & 701 & 3.4 & 1.2 & \\
\hline Celosia argentea & 2207 & 1.39 & 19.8 & 824 & 9.1 & 2.2 & \\
\hline Coccinia grandis & 3064 & 0.60 & 13.0 & 433 & 5.6 & 2.5 & \\
\hline Corchorus trilocularis & 1767 & 0.68 & 18.6 & 175 & 8.4 & 2.9 & \\
\hline Justicia flava & 3419 & 1.48 & 20.6 & 547 & 8.4 & 2.7 & \\
\hline Launaea intybacea & 2070 & 1.45 & 22.0 & 437 & 9.9 & 3.1 & {$[54]$} \\
\hline Leptadenia hastata & 1699 & 0.59 & 14.2 & 214 & 4.2 & 2.0 & \\
\hline Pachycymbium laticoronum & 1128 & 0.43 & 13.2 & 309 & 9.8 & 2.4 & \\
\hline Pentarrhinum insipidum & 1100 & 0.41 & 16.3 & 183 & 6.2 & 2.1 & \\
\hline Portulaca quadrifida & 2193 & 0.87 & 20.1 & 1094 & 6.8 & 2.9 & \\
\hline Amorphophallus gomboczianus ${ }^{\mathrm{a}}$ & 428 & 0.08 & 8.72 & 109 & 1.9 & 1.1 & \\
\hline Ximenia caffra ${ }^{\mathrm{b}}$ & 180 & 0.58 & 1.9 & 110 & 1.1 & 1.3 & \\
\hline Trigonella foenum-graecum & 1038 & 3.2 & 23.14 & 203.5 & ND & 1.0 & \\
\hline Dobera glabra ${ }^{\mathrm{b}}$ & 13.88 & ND & ND & 1.16 & 1.66 & ND & [95] \\
\hline
\end{tabular}

All are green vegetables, unless otherwise mentioned; ${ }^{a}$ tuber; ${ }^{\mathrm{b}}$ fruit. $\mathrm{ND}=$ not determined. 
plant parts in the preparation of traditional remedies to treat human and livestock health problems.

Teklehaymanot and Mirutse [70] reported that 70\% of the wild edible plants were also used as medicine. Some of the plant parts that are used as a food source but are also ingested as a remedy are taken from the following plants: Saba comorensis (Boj.) Pichon, Moringa stenopetala (Bak. f.) Cuf., Ximenia americana L., and Grewia bicolor Juss. Kebebew and Leta [71] reported that from the recorded wild edible plants in the study area at Nech Sar National Park, Ethiopia, 18 species serve the local community both as sources of food and as traditional medicine. These nutraceutical plants are used to treat 14 human ailments or health problems. The fruit of Cordia africana is mentioned as a treatment for diarrhea. The leaves of Solanum nigrum are used to treat abdominal pain, and the roots of Carissa spinarum is a remedy for tapeworm. These three important nutraceutical plants are also mentioned in other studies undertaken in different parts of the country $[26,70,72]$. Among the 16 species (32.7\%) of WEPs that were grouped as nutraceuticals, the finding indicated that these WEPs were used as food and remedy [73]. Table 3 indicates the list of wild edible plants and their medicinal roles. This showed that wild edible plants are also used for their medicinal value besides their food value. The review indicated that Moringa stenopetala, Solanum nigrum, Tamarindus indica, Carissa spinarum, and Ximenia americana are some of WEPs commonly used in different parts of the country as indicated by different scholars $[49,50,71]$.

3.3. Market Values of Wild Edible Plants. Household economic capability to acquire food in the market is a key for the food access pillar [74]. Income and employment can be obtained from the sale or exchange of wild edible fruits, leaves, juice, and local drinks. Income derived from the sale of wild plant species is of particular importance to the poor household. In addition to their use for household consumption, the identified wild edible trees and shrubs are marketable and provide an opportunity to supplement household incomes in the semiarid lowlands of Southern Ethiopia [32]. Wild edible plants also provide other livelihood options in addition to food value. They provide livelihood options in the form of both income generation and subsistence use from different products such as energy construction, shelter/protection, and fodder. Households generate income by selling products in domestic markets and exporting to neighbouring countries, mainly Sudan [49, 50]. According to Balemie and Kebebew [33], income derived from the sale of wild plants is of particular importance to the poorer households, which must supplement food production with cash in order to meet their basic needs.

Abraham in 2016 reported that some of the wild edible trees contributed as additional income sources [75]. For example, Engulmanzy and M. kummel fruits are harvested mostly freely from the wild and sold at the weekly local and daily urban markets in fresh conditions. Market assessment of wild edible plant species showed that most of the edible plants are not sold only for food purposes but also for other purposes such as timber, agricultural tools, construction, and fuel wood purposes. Some of the wild edible plant part(s) such as the fruits of Syzygium guineense, Balanites aegyptiaca, Boswellia neglecta, and Ximenia americana and the leaves of Moringa stenopetala are most commonly sold by women and children and provide the opportunity to supplement household income [71]. A study conducted in Tanzania [5] and Ethiopia [31] also revealed that the sale of wild edible plants supplements low farm returns and contributes additional income to households. The marketability of wild edible plants has revealed that the majority of WEPs (75.7\%) in East Shewa were not marketed. It has been found that $24.3 \%$ were widely marketed from the wild harvest to the local market [26]. The wild edible plants in the Bule Hora Woreda, Southern Ethiopia, are almost not sold as food in the local market except for a few; that is, only Syzygium guineense (Willd.) DC. and Syzygium guineense var. (Wild.) DC. have been sold in the past during the shortage of food in the area.

But these wild edible plants do not sell in the market nowadays. However, the wild edible plant called Tamarindus is still sold in the local market even though there is no food scarcity in the study area [76]. On the other hand, Alemayehu et al. [69] reported that there were no wild edible plants sold in the market at Berehet District, North Shewa Zone of Amhara Region, Ethiopia.

The variation in the marketability of wild edible plants may be due to differences in geographical location, types of wild edible plants, and culture of the society. The list of the most commonly marketed wild edible plants are indicated in Table 4. This review indicates that some wild edible plants (Tamarindus indica, Ximenia americana, and Moringa stenopetala) are marketed in different parts of the country. Besides their food security value, WEPs are sold in the market to generate income.

\subsection{Plant Parts Used and Mode of Consumption of Wild Edible Plants}

3.4.1. Edible Parts of Wild Edible Plants. Fruits, leaves, and gum were the most widely used wild edible plant parts. The parts of wild edible trees and shrubs that are consumed include fruits, seeds, and leaves. Anbessa [76] reported that fruits were the most widely used edible plant parts (79.31), while tubers and fruits (3.45\%), young shoots (6.90\%), young shoots and fruits $(3.45 \%)$, roots $(3.45 \%)$, and gums $(3.45 \%)$ were the remaining edible parts. Another study indicates that among different parts of medicinal and wild edible plants, fruits are the plant parts that are most widely used for medicinal purposes as well as for edible food [52]. The findings of Kebebew and Leta [71] also indicated that from 51 wild edible plant species, about 40 were fruits, 7 were leaves, and 2 were roots and flower nectars each, while the remaining 3 were seed, young shoot, and stem bark [77]. The figures indicated that different parts of wild edible plants are used for consumption. Leaves, fruits, roots, and seeds are parts of wild edible plants commonly used.

Fruit was the dominant part of wild edible plants that was reported to be highly edible in most studies undertaken in different parts of Ethiopia [31, 33, 70, 78]. The increased use of wild fruits compared to other parts of the plant may be because the fruits are used more during seasons of food 
TABLE 3: List of wild edible medicinal plants.

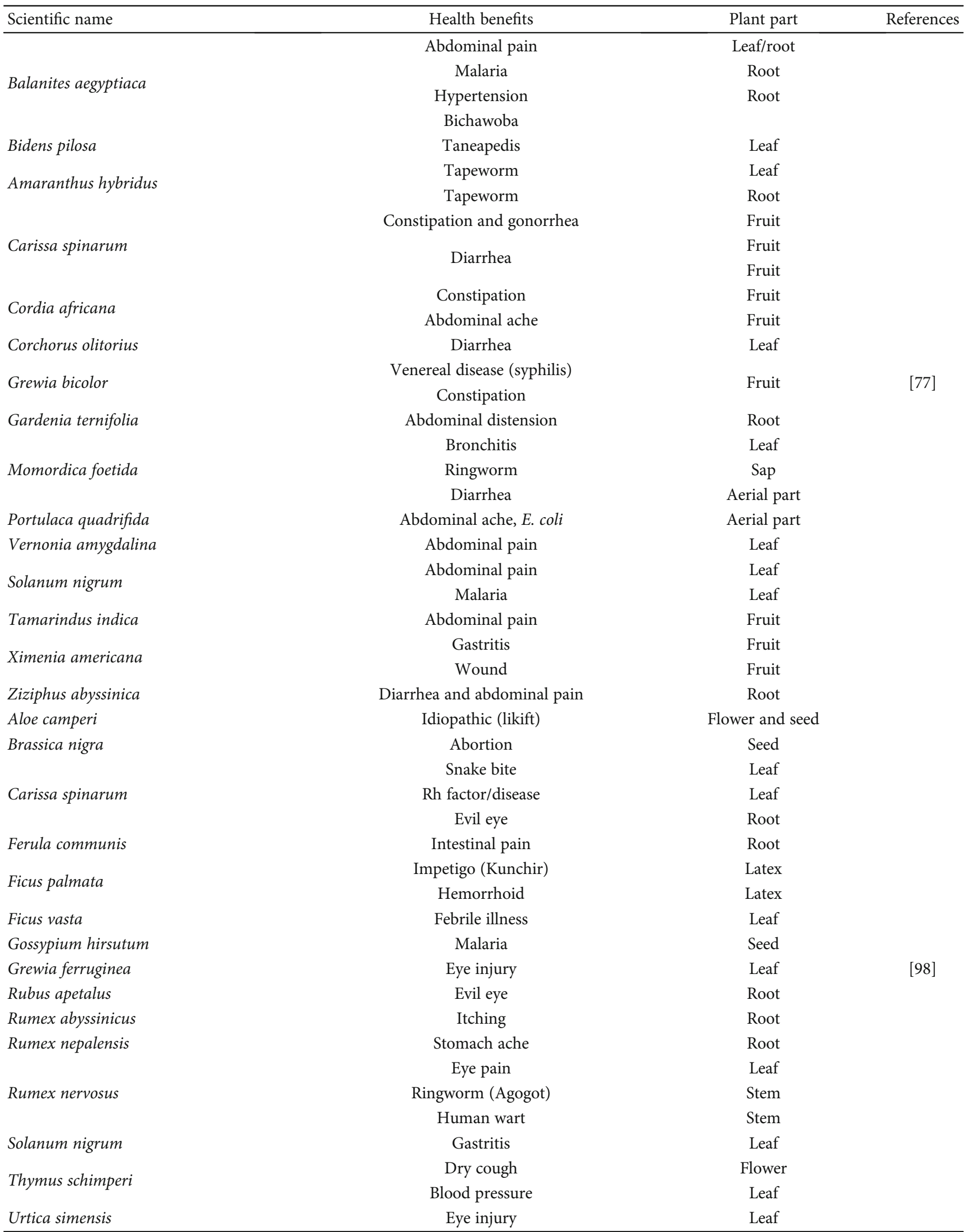


TABLE 3: Continued.

\begin{tabular}{|c|c|c|c|}
\hline Scientific name & Health benefits & Plant part & References \\
\hline Amaranthus caudata & Scrofulous sores & Leaf & \\
\hline Balanites aegyptiaca & Abdominal pain and snake bite & Fruit & \\
\hline Biden spilosa & Snake bites and wound & Leaf & \\
\hline Cadaba farinosa & Stomach ache and snake bite & Leaf & \\
\hline Capsicum annuum & Stomach ache & Fruit & \\
\hline Citrus aurantifolia & Stomach ache and hypertension & Fruit & \\
\hline Cordia africana & Diarrhea & Fruit & \\
\hline Datura stramonium & Dandruff & Flower & \\
\hline Diospyros abyssinica & Malaria and dysentery & Leaf & {$[71]$} \\
\hline Ficus sycomorus & Hepatitis & Sap & \\
\hline Lantana camara & Mosquito repellent & Leaf & \\
\hline Moringa stenopetala & Hypertension and diabetes & Leaf & \\
\hline Solanum nigrum & Abdominal pain & Leaf & \\
\hline Tamarindus indica & Diarrhea & Fruit & \\
\hline Ximenia americana & Abdominal pain & Fruit & \\
\hline Ziziphus mucronata & Dandruff & Leaf & \\
\hline Ziziphus spina-christi & Dandruff & Leaf & \\
\hline Uvaria leptoclada & Respiratory infection and tuberculosis & Root & \\
\hline Saba comorensis & Venereal disease/syphilis & Fruit & \\
\hline Balanite srotundifolia & Gastrointestinal illness and intestinal parasites & Root & \\
\hline Cordia sinensis Lam & Respiratory infection and tuberculosis & Root & \\
\hline Cadaba forinosa Forssk & Gastrointestinal illness and intestinal parasites & Root & [70] \\
\hline Flueggea virosa (Willd.) Voigt & Boils, abscess, and swelling & Root & {$[/ 0]$} \\
\hline Dobera glabra (Forssk.) Poir & Respiratory infection and tuberculosis & Root & \\
\hline Salvadora persica $\mathrm{L}$. & Respiratory infection and tuberculosis & & \\
\hline Lycium shawii Roem. \& Schult & Boils, abscesses, and swelling & Root & \\
\hline Grewia bicolor & Venereal disease/syphilis & Fruit & \\
\hline Maesa lanceolata Forssk. & Snake bite & Leaf & \\
\hline Rhus glutinosa Hochst. & Liver disease & Fruit & \\
\hline Rhus natalensis Bernh. ex C. Krauss & Ear ache & Stem, latex & \\
\hline \multirow{2}{*}{ Rumex abyssinicus Jacq. } & Hearing failure & Stem, latex & \\
\hline & Gastritis & Stem, latex & \\
\hline Acokanthera schimperi & Insect allergy & Fruit & \\
\hline Balanites aegyptiaca & Eye disease & Bark & \\
\hline Carissa spinarum $\mathrm{L}$. & Intestinal parasite & Fruit & \\
\hline Commelina latifolia & Toothache & Stem & [99] \\
\hline Cordia africana Lam & Wound & Leaf & \\
\hline Datura stramonium L. & Wound & Root, leaf & \\
\hline \multirow{2}{*}{ Moringa stenopetala } & Abdominal pain & Leaf & \\
\hline & Malaria & Root & \\
\hline Rumex nervosus Vahl. & Ringworm & Latex & \\
\hline Senna occidentalis (L.) & Amoeba & Leaf & \\
\hline \multirow{2}{*}{ Tamarindus indica L. } & Malaria & Fruit & \\
\hline & Evil spirit & Bark & \\
\hline
\end{tabular}

shortages, and fruit has good taste and flavour because of its chemical composition. However, the result of Amenu [79] and Mesfin et al. [80] indicated that roots are mostly used for medicinal and edible purposes. On the other hand, Guyu and Muluneh [81] reported that $52.4 \%$ of the total amount of wild foods came from wild vegetables, which is about 5 times 
TABLE 4: List of marketable wild edible plants.

\begin{tabular}{lll}
\hline Scientific name of WEPs & $\begin{array}{c}\text { Parts } \\
\text { marketed }\end{array}$ & References \\
\hline Amaranthus caudata & Leaf & \\
Balanites aegyptiaca & Fruit & \\
Boswellia neglecta & Fruit & [71] \\
Colocasia esculenta & Root & \\
Moringa stenopetala & Leaf & \\
Syzygium guineense & Fruit & \\
Sclerocarya birrea (A. Rich.) Hochst & Fruit & \\
Menya tetraphylla (Schweinf. Ex Hiern & Fruit & [32] \\
Opuntia ficus-indica & Fruit & \\
Adansonia digitata L. & Fruit \\
Diospyros abyssinica (Hiem) F. White & Fruit \\
Grewia mollis Juss. & Fruit \\
Saba comorensis (Bo). Pichon & Fruit \\
Tamarindus indica L. & Fruit \\
Carisa spinarum & Fruit \\
Corchorusolitorius & Leaf \\
Diospryos mesiliformis & Fruit \\
Diospyros abyssinica & Fruit \\
Ficus sur & Fruit \\
Hibiscus cannabinus & Fruit \\
Mimusops kummel & Seed \\
Saba comorensis & Fruit \\
Ximenia americana & Fruit \\
Ziziphus spina-christi & Fruit \\
\hline & & \\
& & \\
& &
\end{tabular}

higher than fruits and roots. The variation in consumption of wild edible plant parts might be due to the variation of plant species in adapting to different ecological zones and culture of the people in different areas. Figures 1-3 indicate commonly consumed parts of wild edible plants. Fruits, leaves, tubers, and seeds are parts of wild edible plants consumed in Ethiopia.

3.4.2. Modes of Consumption of Wild Edible Plants. Fruits, leaves, and roots were parts of the plants used for consumption. Most plant parts were eaten directly in fresh forms. The mode of consumption of wild edible plants in Bullen District, Northwest Ethiopia, showed that $57.1 \%$ are consumed raw, $16.9 \%$ are boiled, $6.5 \%$ are consumed in juice form, $9.1 \%$ are either consumed raw or boiled, and 5.2\% are consumed as porridge/sauce [77]. The study of Beche et al. [82] also indicated that the majority of the recorded edible species were consumed fresh without ripening or processing. The study conducted by Tebkew et al. [50] at Quara District, Northwest Ethiopia, indicated that wild edible plants were consumed fresh, dried and cooked, or prepared in different forms. Majority of the edible plants were consumed fresh, while only nine of them were consumed after drying. In Bule Hora Woreda, Southern Ethiopia, the local people reported that majority of the wild edible plants in the area were con- sumed raw (about 89.66\%), except for Amaranthus caudatus L., Dioscore abulbifera L., and Premna schimperi Engl. whose edible parts can be cooked, boiled, and fermented, respectively, for intake. There was no need for cooking, boiling, or roasting the edible parts for consumption in the majority of wild edible plants in the area [76]. Ashagre et al. [83] also reported that most of the plant parts $(87 \%)$ were eaten uncooked (raw), while some of them (6.5\%) needed processing and cooking to make them suitable for consumption and a few of them (6.5\%) could be eaten either cooked or uncooked. Alemayehu et al. [69] reported that about 49 species (92\%) of these fruits were reported to be eaten raw, whereas 4 species (8\%) were consumed cooked or processed. Different studies indicated that most wild edible plants are consumed raw without further processing (cooking and spicing) in different parts of Ethiopia [71, 76, 77].

Seyoum Aragaw [34] indicated that nearly half of the identified plant species are consumed raw, and many of them are fruits. Others are used after various food preparation techniques. For instance, starchy staples such as tubers have to be cooked to destroy toxic compounds. Leafy vegetables are used after frying and/or boiling or steaming over a fire, and some fruits can be used following non-fire-processing methods like Rubus apetalus, which is consumed in the form of a juice. About 52\% are used raw as snacks, $19 \%$ are cooked, $16 \%$ are processed, and $12 \%$ of the identified plant species can be used after certain processing and cooking steps. About $1 \%$ of the identified plant species can be used raw, cooked, or processed, and hence are of multimodal consumption importance.

3.5. Preferences of Wild Edible Plants. The preference of wild edible plants varied; some of the wild edible plants are consumed only during famine and not consumed during normal periods [77]. The individual preference for wild edible plant consumption varies from one locality to another [71]. The condition or time when each plant is consumed also varies. Some plants are consumed always even in the presence of appreciable food stock, while others are consumed only at times of acute food shortage and scarcity ([31]; Assefa and Abebe, 2014; [84]). Plants that are consumed at normal periods are highly valued during periods of food scarcity at all levels. Majority of the wild edible plants in the area were eaten as extra food instead of being served as regular meals. This indicates the use of wild edible plants for other purposes such as materials for house construction and as charcoal during periods when there is sufficient access to cultivated plants.

Likewise, the optional consumption of wild plants was happening in different parts of the world [85]. According to the report of Ashagre et al. [83], wild edible plants are an integral part of the diet of the local people in Burji District, Segan Area Zone of the Southern Nations, Nationalities, and Peoples Region (SNNPR), Ethiopia, at times of both food plenty and scarcity. Most wild edible plants recorded in the Derashe and Kucha Districts of south Ethiopia are consumed both in normal periods and during food scarcity. However, about $27.3 \%$ of wild edible plants are consumed only when the preferred alternatives are not available [33]. 


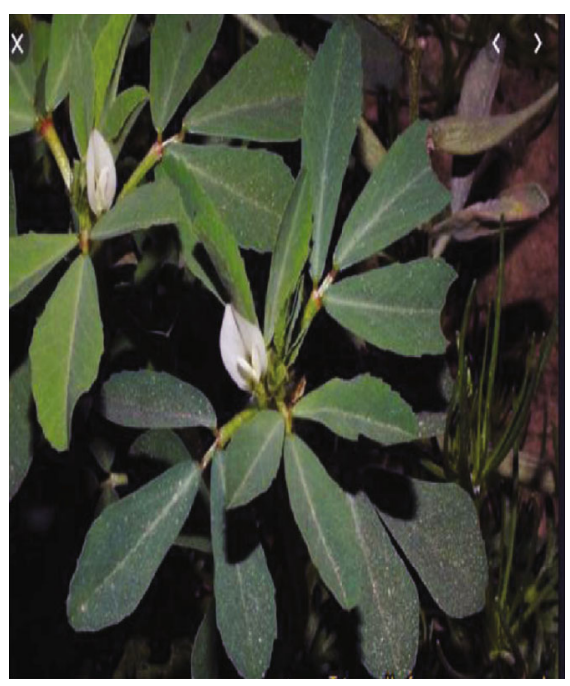

Trigonella foenum-graecum

(a)

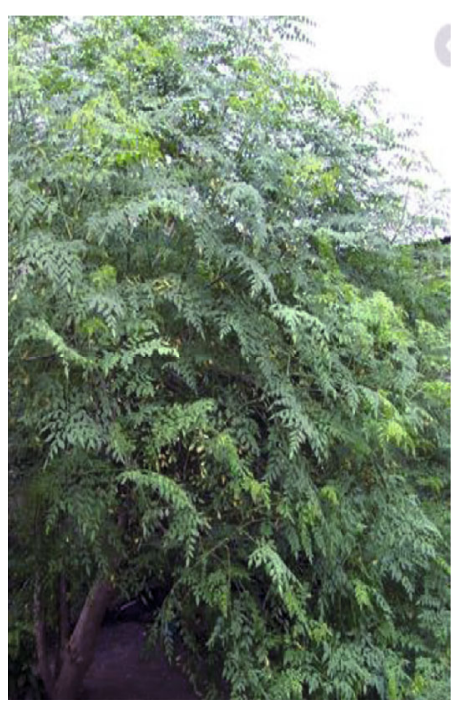

Moringa stenopetala

(c)

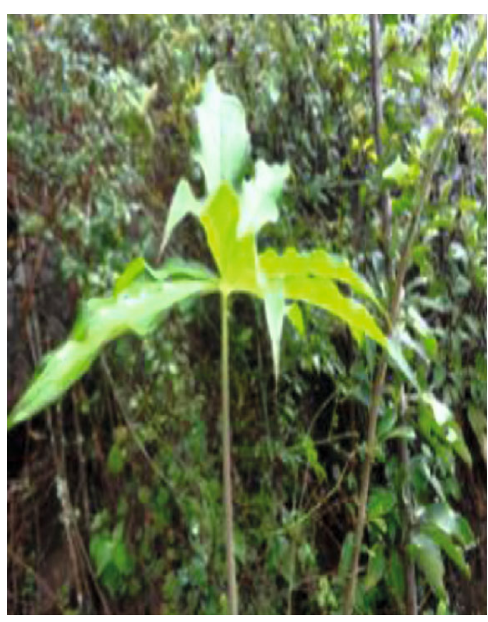

Arisaema schimperianum

(e)

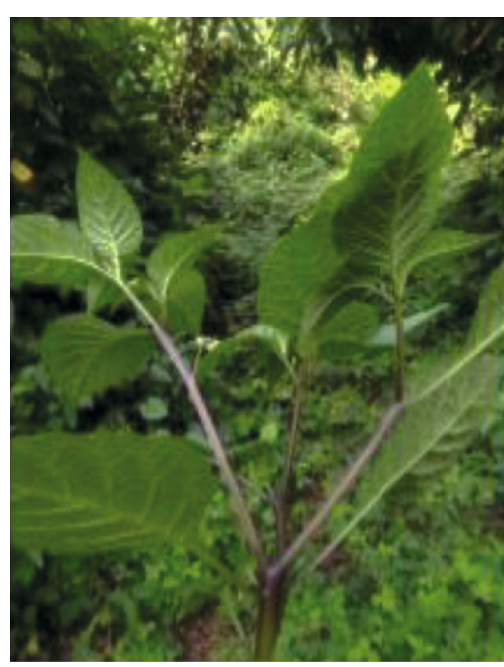

Solanum nigrum

(b)

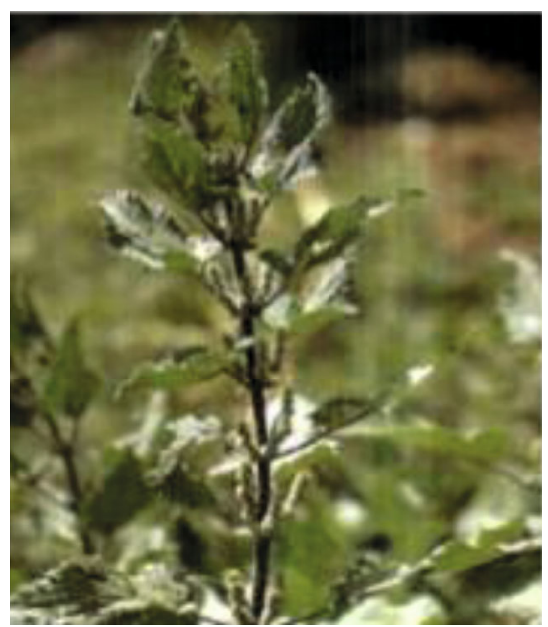

Utric simensis Steudel

(d)

FIgURE 1: Commonly used wild edible leaves (a-e). 


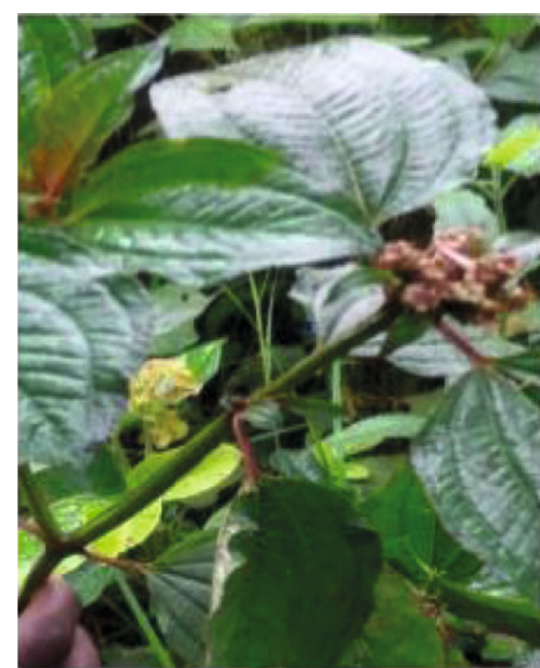

Tristemma mauritianum

(a)

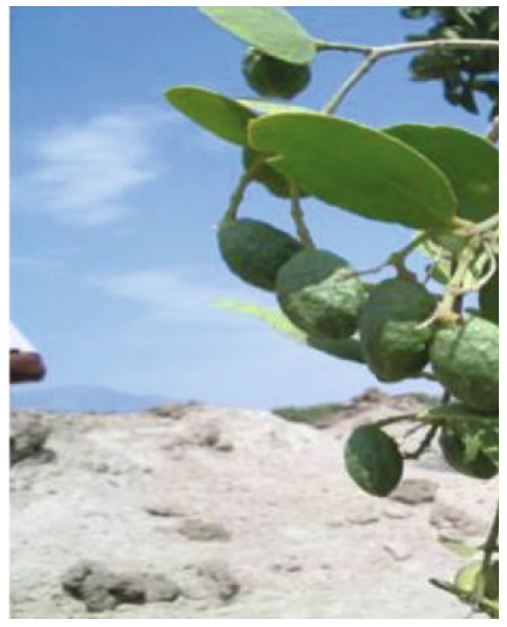

Dober glabra

(c)

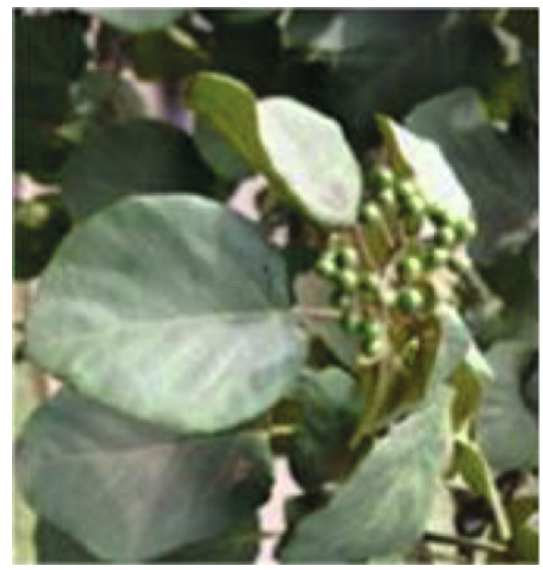

Cordia africana Lam

(e)

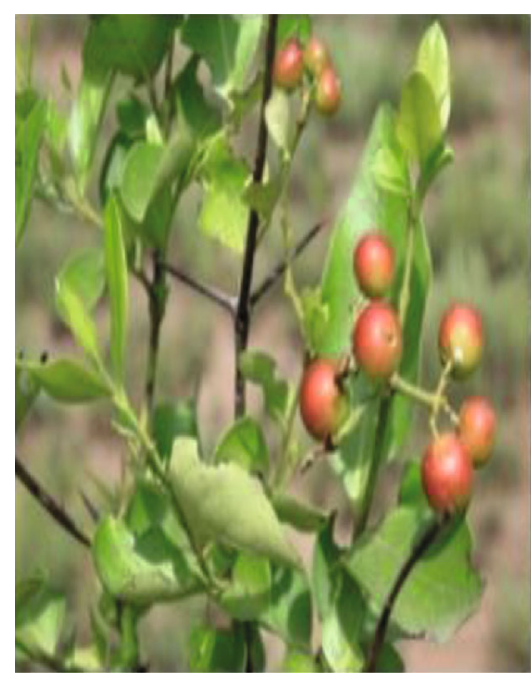

Carissa spinarum

(b)

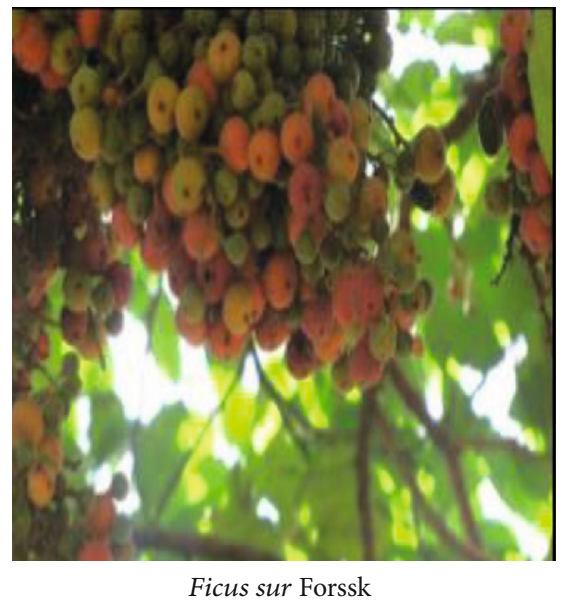

(d)

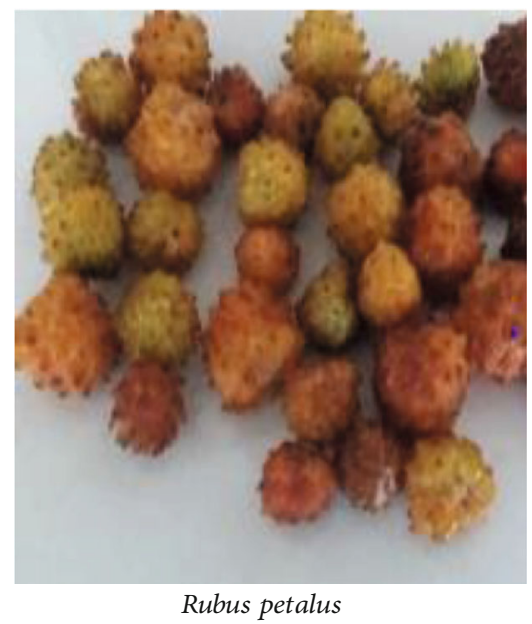

(f)

Figure 2: Continued. 


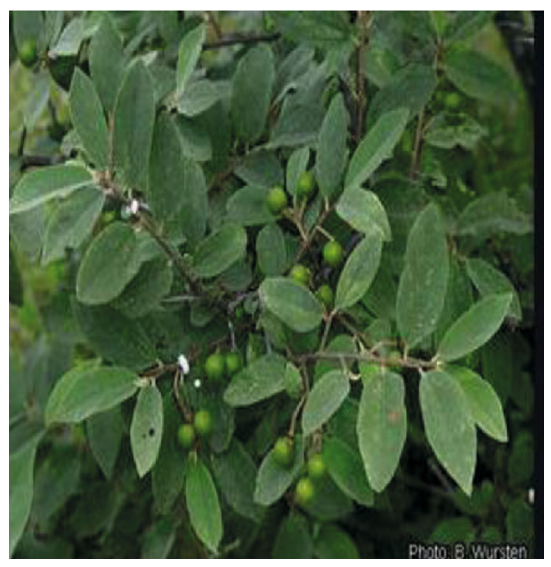

Grewia bicolor

(g)

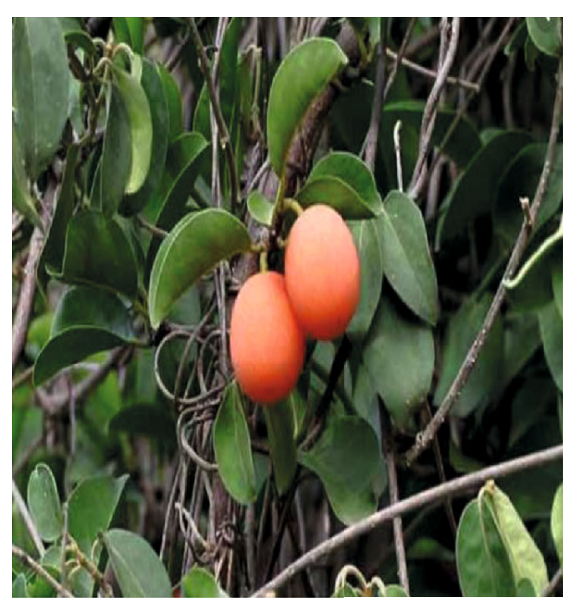

Ximenia americana

(h)

Figure 2: List of commonly consumed wild edible fruits (a-h).

\section{Attitudes of Consumers to Wild Edible Plants}

There was a strong belief, mainly by the indigenous people, that wild foods have a greater capacity to maintain the good health conditions of those who depend on them [81]. Anbessa [76] indicated that the majority of wild edible plants were eaten as extra food rather than as regular meals. Over $70 \%$ of the wild edible plants were consumed during times of food scarcity and starvation, when the supplies of stored food crops were declining progressively [70]. The general public consumes most of the WEPs as snacks, supplements, or refreshments. So, most of the indigenous people of the area occasionally consider the WEPs as famine foods or foods for conditions of starvation. Around $73.33 \%$ of the WEPs were used as supplementary food, while the rest $(26.67 \%)$ were used as regular food or as meals [52]. This implies that most of society consider WEPs as famine food.

Consumption of wild edible plants carries the connotation of belonging to a lower strata in society and is considered an insult, because of lack of knowledge [18]. Similarly, in Kayissa Kebele, South Omo Zone, 10 WEPs are not consumed by the majority of the population except when there is a serious shortage of food affecting all strata of the population from the poorest to the richest [16]. Different studies in Ethiopia show that the local taboos seem to dread being fully depressed to the point of consuming WEPs $[18,49]$. Although WEPs play an important role in food security, their utilization was constrained by different factors like cultural ignorance, difficulty of collection, and being choice foods [49]. In a similar study, Addis et al. [86] indicated that despite the fact there was a common understanding and belief that WEPs are important to bridge gaps of food deficiency and serve as food supplements, some individuals in communities consider the use of WEPs as a sign of underdevelopment and poverty. This is a serious threat to conservation and consumption of wild edible plants. On the other hand, Addis et al. [31] stated that wild plants in Ethiopia are used as a source of food both at times of plenty and at times of food shortages. Households have indicated the desire to continue to gathering and hunting for wild foods, but the amount they obtained was very low due because the availability of wild foods have been currently reduced due to substitution with staple crops, wild foods are not culturally acceptable, and the hunting and gathering of wild foods have been legally banned [81]. The literature indicates that the perception of wild edible plants as food varies from location to location, and it also varies with economic status, gender, and age of the consumer.

\section{Threats and Challenges for Utilization of WEPs}

Wild edible plants are threatened with various human and natural factors like land use change (expansion of agricultural lands), developmental activities (road construction and urbanization), habitat destruction (timber harvest, fuel wood collection, and wildfire), drought, overharvesting, and overgrazing. These are among the main factors that reduce the diversity and density of wild edible plants in the study area. The finding of Amente [52] indicated that agricultural activities and drought are the major threatening factors followed by construction, overgrazing, fuel wood collection, and urbanization. Similarly, Kebede et al. [87] reported that deforestation and human encroachment ranked as the 1st and 2nd major factors, respectively, followed by drought and firewood collection in the $3 \mathrm{rd}$ and 4th places, respectively. In comparison, Balemie and Kebebew [33] reported that drought takes the major part followed by fuel wood collection and selective cutting for construction.

Despite their accessibility and availability, the utilization of wild edible plants is challenged by numerous factors. Tebkew et al. [50] reported in their findings that the difficulty of collecting, the fast deterioration of products, the perception of being a choice/alternative food, cultural ignorance, and lack of awareness about the nutritional value of the products were the major challenges for the utilization of wild edible plants. Among the challenges, using the products as alternative food and ignorance by culture were the main challenges at about 


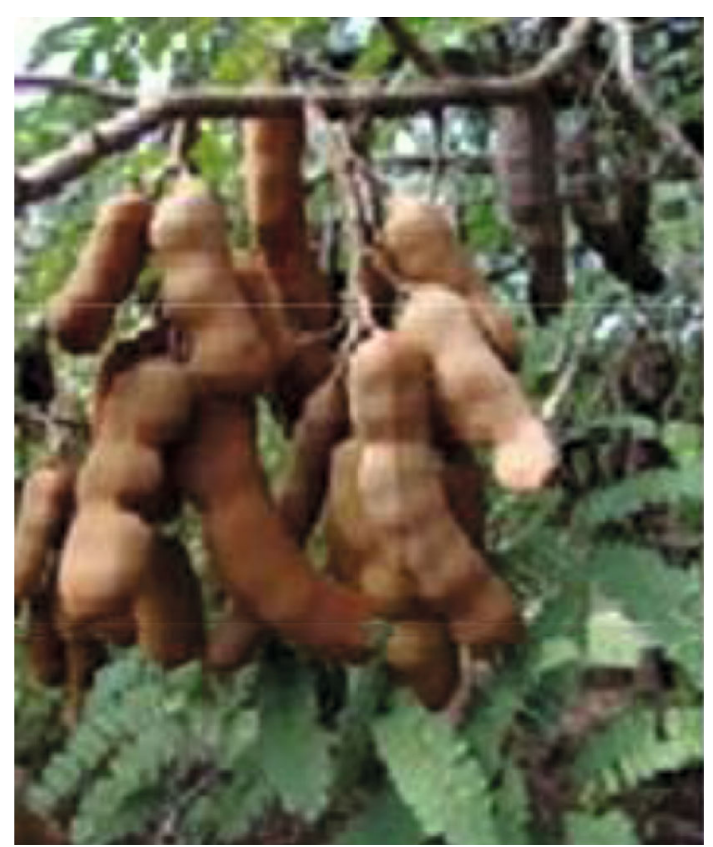

Tamarindus indica

(a)

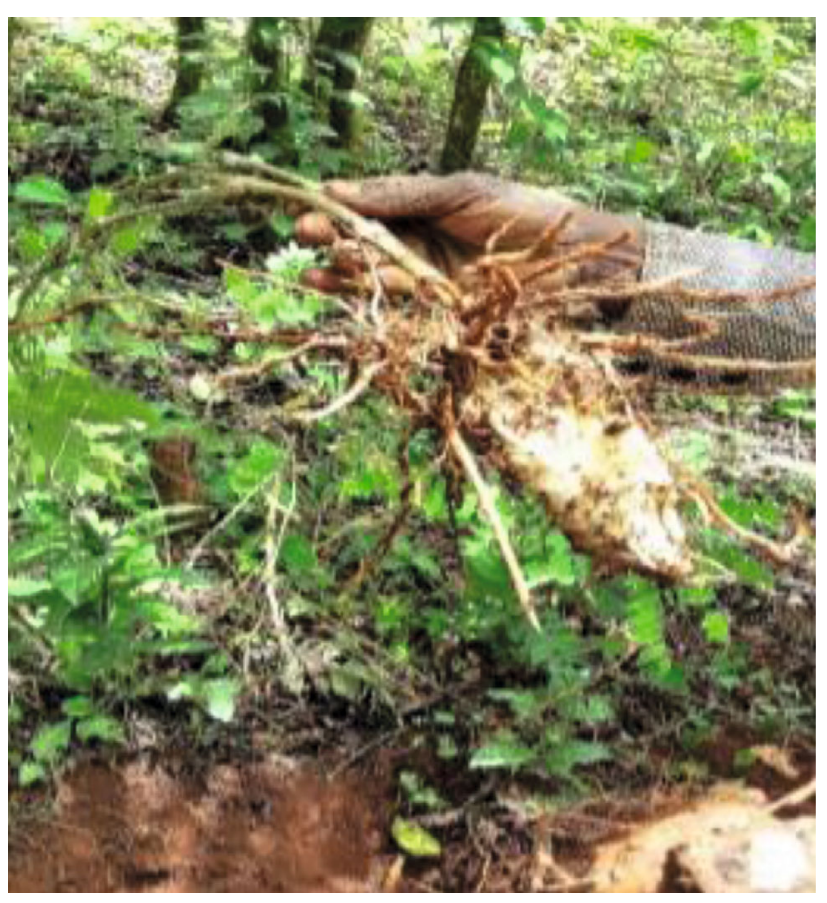

Dioscorea prehensilis

(b)

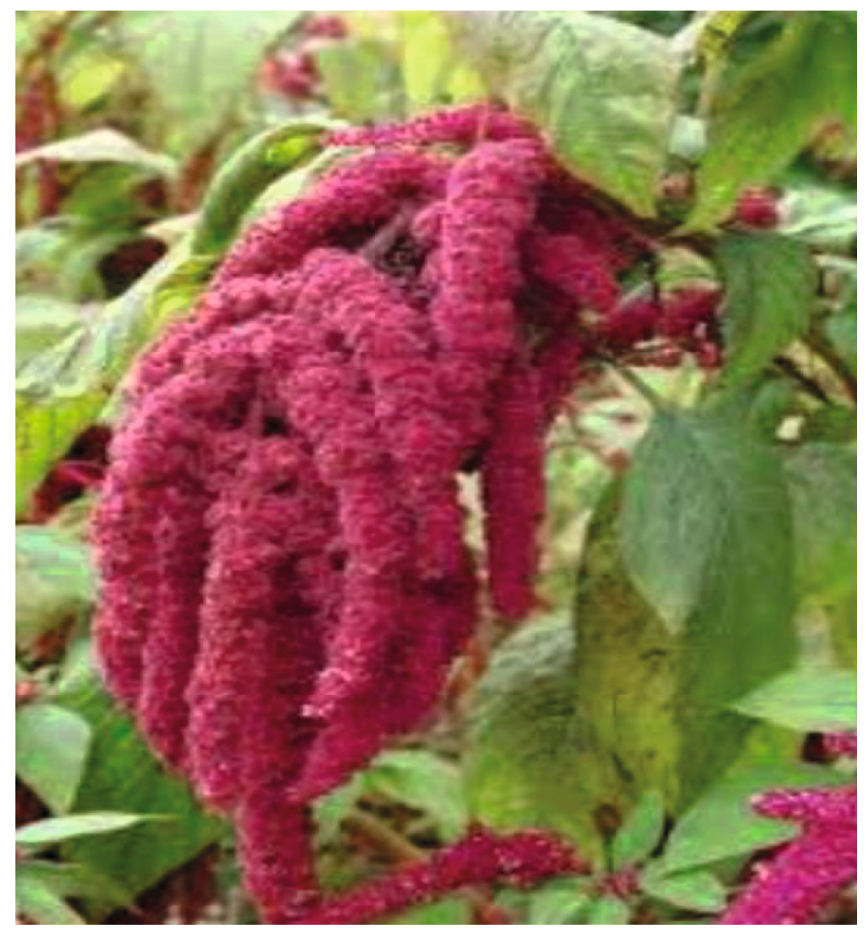

Amaranthus seed

(c)

Figure 3: Commonly consumed wild edible tubers ( $\mathrm{a}$ and $\mathrm{b}$ ) and seed (c).

$53 \%$ and $44 \%$, respectively. The consumption of WEPs is influenced by different problems: the natural environment where WEPs grow makes them very difficult to collect and their deterioration within a short period reduces the quality and value of WEPs, which might cause people to ignore them and shift to other staple foods $[18,50]$. Rapid deterioration of WEPs may be due to improper harvesting and postharvest handling practices. 


\section{Inclusion of Wild Edible Plants in Policy for Nutritional Security}

Assimilation of wild edible plants into the diet has much larger implications in terms of environmental sustainability, when the world is plagued with the grave crises of climate change and food insecurity, and could lessen the footprints of agriculture and allow for a shift toward more sustainable food systems [88]. Malnutrition is a major health burden in developing countries, and the recognition that nutritional security and biodiversity are linked is fundamental for enlisting policy support to secure wild food use and preserve habitats for wild edible species [42]. Wild food offers several advantages along this line, i.e., wide diversity, easy access to the local resource base, availability, time-tested reliability, and little or no management $[42,89,90]$. Moreover, the problem of micronutrient deficiency or "hidden hunger" that looms large over the global population cannot be erased by staple crops which lack essential micronutrients [41, 91].

Diets in Ethiopia are low in diversity and are lacking in the critical components of a healthy diet such as fruits and vegetables. The low production of fruits and vegetables and their seasonality and unaffordability constrain Ethiopians from reaping the health benefits provided by regular consumption of fruits and vegetables. Wild edible plants have the potential to greatly improve diets by providing alternative sources of more affordable, nutritionally rich fruits and vegetables, with the added advantage of being available all year round and having the ability to grow in drought-prone, water-stressed areas. However, integrating wild edible fruits and vegetables into markets and designing a functional and efficient value chain is key to ensuring increased availability and consumption [92]. Policies, extension activities, and system sensitivity factors might be wont to identify groups that consume WEPs more frequently, helping NGOs and governments to focus on relevant projects more effectively. This is becoming more important as limited resources restrict food security initiatives in rural areas, despite an increased need for these programs in the face of changing climate and increasingly vulnerable smallholder farms [93]. Moreover, Dejene et al. [94] suggested that due to the diversity of wild edible trees, conservation and management strategies are needed to achieve food security from the use of forest resources. Generally, the review confirmed that food security and agricultural policies have to focus on the contribution of wild edible foods as one pillar to food security.

\section{Conclusion}

The present article is an attempt to review the available information regarding the nutritional contribution, supplementary role, and medicinal value of wild edible plants in Ethiopia and determine consumer attitudes toward them. WEPs have a major contribution to the dietary intake of a community, either for use in times of seasonal food shortage, for filling a food gap and supplementing staple food in normal times, and for use as emergency food during famine. Wild edible plants have the potential to greatly improve food security by providing alternative sources of affordable and nutritious food with the added advantage of being available all year round and being able to grow in water-stressed areas and diverse environmental conditions. Fruits are the dominant parts of wild edible plants used for medicinal purposes as well as for consumption. Besides nutritional contributions, WEPs are used as medicine to treat different human diseases and are sold to generate income for rural people. In spite of its high nutritional contribution, wild edible plants are considered as food for poor families. Wild edible plants demand due consideration to fight food insecurity and improve rural livelihood. Nutrition policies have to promote the utilization of WEPs as part of a strategy to improve food security, nutrition, and livelihoods of rural communities throughout the country. Further investigation is needed on the bioactive compound and antinutritional factor contents of wild edible plants.

\section{Data Availability}

The materials described in the manuscript, including all relevant raw data, will be freely available to any scientist wishing to use them for noncommercial purposes.

\section{Conflicts of Interest}

The author declares no conflicts of interest.

\section{Acknowledgments}

This review article contains information collected from various published resources; thus, I would like to acknowledge all authors of the references used in this review.

\section{References}

[1] Food and Agriculture Organisation of the United Nations, The state of food insecurity in the world: economic growth is necessary but not sufficient to accelerate reduction of hunger and malnutrition, FAO, Rome, Italy, 2012, http://www.fao.org/ publications/sofi/2012/en/.

[2] Food and Agriculture Organisation of the United Nations, The state of food insecurity in the world: how does international price volatility affect domestic economies and food security?, FAO, Rome, Italy, 2011, http://www.fao.org/docrep/014/ i2330e/i2330e00.htm.

[3] Chennai Platform for Action, "Agricultural biodiversity and elimination of hunger and poverty: UN Millennium Development Goals," 2006, http://cgiar.org/Events/IFAD-NUS/PDF/ Agreement5.

[4] G. Addis, Edible wild and semi-wild plants of Hamar and Xonso (South Ethiopia) with emphasis on their ethnobotany and nutritional composition of selected species, [Ph.D. Thesis], Addis Ababa University, Addis Ababa, 2009.

[5] C. K. Ruffo, A. Birnie, and B. Tengnäs, Edible Wild Plants of Tanzania, Regional land management unit, SIDA, Nairobi, Kenya, 2002.

[6] D. Teketay, M. Lemenih, T. Bekele et al., "Forest resources and challenges of sustainable forest management and conservation in Ethiopia," in Degraded Forests in Eastern Africa, pp. 31-75, Routledge, 2010.

[7] N. Sekeroglu, F. Ozkutlu, M. Deveci, O. Dede, and N. Yilmaz, "Evaluation of some wild plants aspect of their nutritional 
values used as vegetable in Eastern Black Sea Region of Turkey," Asian Journal of Plant Sciences, vol. 5, no. 2, pp. 185189, 2006.

[8] A. Cavender, "Folk medical uses of plant foods in southern Appalachia, United States," Journal of Ethnopharmacology, vol. 108, no. 1, pp. 74-84, 2006.

[9] A. Pieroni, L. Houlihan, N. Ansari, B. Hussain, and S. Aslam, "Medicinal perceptions of vegetables traditionally consumed by south-Asian migrants living in Bradford, northern England," Journal of Ethnopharmacology, vol. 113, no. 1, pp. 100-110, 2007.

[10] A. Dansi, A. Adjatin, H. Adoukonou-Sagbadja et al., "Traditional leafy vegetables and their use in the Benin Republic," Genetic Resources and Crop Evolution, vol. 55, no. 8, pp. 1239-1256, 2008.

[11] S. Mavengahama, M. McLachlan, and W. De Clercq, "The role of wild vegetable species in household food security in maize based subsistence cropping systems," Food Security, vol. 5, no. 2, pp. 227-233, 2013.

[12] S. D. Yumkham, L. Chakpram, S. Salam, M. K. Bhattacharya, and P. K. Singh, "Edible ferns and fern-allies of North East India: a study on potential wild vegetables," Genetic Resources and Crop Evolution, vol. 64, no. 3, pp. 467-477, 2017.

[13] Food and Agriculture Organization of the United Nations, Wild food plants: agrobiodiversity strategies to combat food insecurity and HIVIAIDS impact in rural Africa, Food and Agriculture Organization, 2003.

[14] Food and Agricultural Organization of the United Nations, Forests for improved nutrition and food security, FAO, 2010.

[15] A. Getahun, "The role of wild plants in the native diet in Ethiopia," Agroecosystems, vol. 1, pp. 45-56, 1974.

[16] Y. Guinand and D. Lemessa, Wild-food plants in Southern Ethiopia: reflections on the role of famine-foods at a time of drought, UNDP-EUE Field Mission Report, Addis Ababa, 2000.

[17] T. Soromessa and S. Demissew, "Some uses of plants by the Benna, Tsemay and Zeyise people, Southern Ethiopia," Ethiopian Journal of Natural Resources, vol. 4, no. 1, pp. 107-122, 2002.

[18] M. T. Fentahun and H. Hager, "Exploiting locally available resources for food and nutritional security enhancement: wild fruits diversity, potential and state of exploitation in the Amhara region of Ethiopia," Food Security, vol. 1, no. 2, pp. 207-219, 2009.

[19] V. Urso, M. A. Signorini, M. Tonini, and P. Bruschi, "Wild medicinal and food plants used by communities living in Mopane woodlands of southern Angola: results of an ethnobotanical field investigation," Journal of Ethnopharmacology, vol. 177, pp. 126-139, 2016.

[20] H. Kaoma and C. M. Shackleton, "The direct-use value of urban tree non-timber forest products to household income in poorer sub-urbs in South African towns," Forest Policy and Economics, vol. 61, pp. 104-112, 2015.

[21] M. Rathore, "Nutrient content of important fruit trees from arid zone of Rajasthan," Journal of Horticulture and Forestry, vol. 1, pp. 103-108, 2009.

[22] C. Termote, G. Everaert, M. B. Meyi, B. D. Djailo, and P. Van Damme, Wild edible plant markets in Kisangani, no. 2, 2012Human Ecology, Democratic Republic of Congo, 2012.

[23] S. Chakravarty, K. D. Bhutia, C. P. Suresh, G. Shukla, and N. A. Pala, "A review on diversity, conservation and nutrition of wild edible fruits," Journal of Applied and Natural Science, vol. 8, no. 4, pp. 2346-2353, 2016.

[24] E. Lulekal, Z. Asfaw, E. Kelbessa, and P. Van Damme, "Wild edible plants in Ethiopia: a review on their potential to combat food insecurity," Africa Focus, vol. 24, no. 2, 2011.

[25] T. Awas, Plant diversity in Western Ethiopia: ecology, ethnobotany and conservation, [Ph.D. thesis], Faculty of Mathematics and Natural Sciences, University of Osla, Norway, 2007.

[26] D. H. Feyssa, J. T. Njoka, Z. Asfaw, and M. M. Nyangito, "Seasonal availability and consumption of wild edible plants in semiarid Ethiopia: implications to food security and climate change adaptation," Journal of Horticulture and Forestry, vol. 3, no. 5, pp. 138-149, 2011.

[27] T. Van Andel, "Non-Timber Forest Products: The Value of Wild Plants," in Agromisa Foundation and CTA Vegetation of Cheffa, Agrodok 39, Addis Ababa University Press, Wageningen: Addis Ababa, Ethiopia, 2006.

[28] J. Bell, “The hidden harvest,” Seedling. The Quarterly Newsletter of Genetic Resources Action International (GRAIN), 1999, http://www.grain.org.

[29] E. Kelbessa and S. Demissew, "Diversity of vascular plant taxa of the flora of Ethiopia and Eritrea," Ethiopian Journal of Biological Sciences, vol. 13, pp. 37-45, 2014.

[30] Y. Yonas, "The remnant forests of Ethiopia," in Proceedings of a national conference on forest resource of Ethiopia: status, challenges and oportunities, Institution of Biodiversity Conservation (IBC), Addis Ababa, Ethiopia, 2004.

[31] G. Addis, K. Urga, and D. Dikasso, "Ethnobotanical study of edible wild plants in some selected districts of Ethiopia," Human Ecology, vol. 33, no. 1, pp. 83-118, 2005.

[32] A. Assefa and T. Abebe, "Wild edible trees and shrubs in the semi-arid lowlands of southern Ethiopia," Journal of Science and Development, vol. 1, no. 1, pp. 5-19, 2011.

[33] K. Balemie and F. X. Kebebew, "Ethnobotanical study of wild edible plants in Derashe and Kucha Districts, South Ethiopia," Journal of Ethnobiology and Ethnomedicine, vol. 2, p. 53, 2015.

[34] H. Seyoum Aragaw, Nutritional potential of underutilized edible plants in agroforestry systems of Yayu, Southwestern Ethiopia, University of Bonn, 2017.

[35] F. K. Huber, R. Ineichen, Y. P. Yang, and C. S. Weckerle, "Livelihood and conservation Aspects of Non-wood Forest Product Collection in the Shaxi Valley, Southwest China1," Economic Botany, vol. 64, no. 3, pp. 189-204, 2010.

[36] C. Kleinn, Y. Yang, H. Weyerhäuser, and M. Stark, "The sustainable harvest of non-timber forest products in China," in Strategies to balance economic benefits and biodiversity conservation, Sino-German Center for Research Promotion, Göttingen, Germany. Beijing, 2006.

[37] T. Seifu, B. Mehari, M. Atlabachew, and B. Chandravanshi, "Polyphenolic content and antioxidant activity of leaves of Urtica simensis grown in Ethiopia," Latin American Applied Research, vol. 47, pp. 35-40, 2017.

[38] K. A. Sir Elkhatim, R. A. Elagib, and A. B. Hassan, "Content of phenolic compounds and vitamin $\mathrm{C}$ and antioxidant activity in wasted parts of Sudanese citrus fruits," Food Science \& Nutrition, vol. 6, no. 5, pp. 1214-1219, 2018.

[39] J. Zhang, Y. Ding, H. Dong, H. Hou, and X. Zhang, "Distribution of phenolic acids and antioxidant activities of different bran fractions from three pigmented wheat varieties," Journal of Chemistry, vol. 2018, Article ID 6459243, 9 pages, 2018. 
[40] A. D. Jones, "Critical review of the emerging research evidence on agricultural biodiversity, diet diversity, and nutritional status in low- and middle-income countries," Nutrition Reviews, vol. 75, no. 10, pp. 769-782, 2017.

[41] P. Pingali, "Agricultural policy and nutrition outcomes-getting beyond the preoccupation with staple grains," Food Security, vol. 7, no. 3, pp. 583-591, 2015.

[42] Z. Bharucha and J. Pretty, "The roles and values of wild foods in agricultural systems," Philosophical Transactions of the Royal Society B: Biological Sciences, vol. 365, no. 1554, pp. 2913-2926, 2010.

[43] O. C. Aworh, "Promoting food security and enhancing Nigeria's small farmers' income through value-added processing of lesser-known and under-utilized indigenous fruits and vegetables," Food Research International, vol. 76, pp. 986-991, 2015.

[44] C. Bvenura and D. Sivakumar, "The role of wild fruits and vegetables in delivering a balanced and healthy diet," Food Research International, vol. 99, Part 1, pp. 15-30, 2017.

[45] M. Ali, R. Jamous, and J. Shafie, "Traditional knowledge of wild edible plants used in Palestine (Northern West Bank): a comparative study," Journal of Ethnobiology and Ethnomedicine, vol. 4, pp. 1-13, 2008.

[46] J. C. Onyekwelu, O. Oyewale, and B. Stimm, "Antioxidant, nutritional and anti-nutritional composition of Garcinia kola and Chrysophyllum albidum from rainforest ecosystem of Ondo State, Nigeria," Journal of Forestry Research, vol. 26, no. 2, pp. 417-424, 2015.

[47] R. R. B. Leakey, "Domestication potential of Marula (Sclerocarya birrea subsp. caffra) in South Africa and Namibia: 3. Multiple trait selection," Agroforestry Systems, vol. 64, no. 1, pp. 51-59, 2005.

[48] Hinnawi, An ethnobotanical study of wild edible plants in the Northern West Bank of Palestine, [M.S. thesis], An-Najah National University, Nablus, Palestine, 2010.

[49] M. Tebkew, "Wild and semi-wild edible plants in Chilga District, North western Ethiopia: implication for food security and climate change adaptation," Global Journal of Wood Science, Forestryand Wildlife, vol. 3, no. 3, pp. 72-82, 2015.

[50] M. Tebkew, Y. Gebremariam, T. Mucheye, A. Alemu, A. Abich, and D. Fikir, "Uses of wild edible plants in Quara district, northwest Ethiopia: implication for forest management," Agriculture \& Food Security, vol. 7, no. 1, p. 12, 2018.

[51] Y. Ju, J. Zhuo, B. Liu, and C. Long, "Eating from the wild: diversity of wild edible plants used by Tibetans in Shangri-la region, Yunnan, China," Journal of Ethnobiology and Ethnomedicine, vol. 9, no. 1, p. 28, 2013.

[52] D. A. Amente, "Ethnobotanical survey of wild edible plants and their contribution for food security used by Gumuz people in Kamash Woreda; Benishangul Gumuz Regional State; Ethiopia," Journal of Food and Nutrition Sciences, vol. 5, no. 6, pp. 217-224, 2017.

[53] P. M. Maundu, G. W. Ngugi, and C. H. S. Kabuye, Traditional Food Plants of Kenya, National Museum of Kenya, 1999.

[54] G. A. Getachew, Z. Asfaw, V. Singh, Z. Woldu, J. J. Baidu-Forson, and S. Bhattacharya, "Dietary values of wild and semiwild edible plants in Southern Ethiopia," African Journal of Food, Agriculture, Nutrition and Development, vol. 13, no. 2, 2013.

[55] J. Agea, C. Okia, R. Abohassan et al., "Wild and semi-wild food plants of Bunyoro-Kintara Kingdom of Uganda: growth forms, collection niches, parts consumed, consumption patterns, main gatherers and consumers," Environmental Research Journal, vol. 2, no. 5, pp. 74-86, 2011.

[56] P. García-Herrera, M. C. Sánchez-Mata, M. Cámara et al., "Nutrient composition of six wild edible Mediterranean Asteraceae plants of dietary interest," Journal of Food Composition and Analysis, vol. 34, no. 2, pp. 163-170, 2014.

[57] P. C. Phondani, I. D. Bhatt, V. S. Negi, B. P. Kothyari, A. Batt, and R. K. Maikhuri, "Promoting medicinal plants cultivation as a tool for biodiversity conservation and livelihood enhancement in Indian Himalaya," Journal of Asia-Pacific Biodiversity, vol. 9, no. 1, pp. 39-46, 2016.

[58] Wold Health Organization, General Guidelines for Methodologies on Research and Evaluation of Traditional Medicine, WHO, Geneva, Switzerland, 2000.

[59] T. Flatie, T. Gedif, K. Asres, and T. Gebre-Mariam, "Ethnomedical survey of Berta ethnic group Assosa Zone, Benishangul-Gumuz regional state, mid-west Ethiopia," Journal of Ethnobiology and Ethnomedicine, vol. 5, no. 1, p. 14, 2009.

[60] K. D. Kassaye, A. Amberbir, B. Getachew, and Y. Mussema, "A historical overview of traditional medicine practices and policy in Ethiopia," Ethiopian Journal of Health Development, vol. 20, no. 2, pp. 127-134, 2006.

[61] A. Lewington, "Medicinal Plants Extract," in A Review of Their Importation into Europe, Traffic International, Cambridge, U.K., 1993.

[62] E. M. Alissa and G. A. Ferns, "Dietary fruits and vegetables and cardiovascular diseases risk," Critical Reviews in Food Science and Nutrition, vol. 57, no. 9, pp. 1950-1962, 2017.

[63] S. Shaheen, M. Ahmad, and N. Haroon, "Nutritional contents and analysis of edible wild plants," in Edible Wild Plants: An Alternative Approach to Food Security, pp. 127-133, Springer, Basel, Switzerland, 2017.

[64] K. Aryal, Å. Berg, and B. Ogle, "Uncultivated plants and livelihood support-a case study from the Chepang people of Nepal," Ethnobotany Research and Applications, vol. 7, pp. 409-422, 2009.

[65] M. Batal, S. Hamadeh, N. Hwalla, N. Kabbani, and S. X. Talhouk, Wild edible plants: promoting dietary diversity in poor communities of Lebanon, final technical report American University of Beirut, Lebanon, 2015.

[66] E. Bekele, Study on actual situation of medicinal plants in Ethiopia, Prepared for Japan Association for International Collaboration of Agriculture and Forestry, Addis Ababa, Ethiopia, 2007.

[67] T. Sori, M. Bekana, G. Adugna, and E. Kelbessa, "Medicinal plants in the ethno veterinary practices of Borana pastoralists, Southern Ethiopia," International Journal of Applied Research in Veterinary Medicine, vol. 2, no. 3, pp. 220-225, 2004.

[68] T. Awas and S. Demissew, "Ethnobotanical study of medicinal plants in Kafficho people, southwestern Ethiopia," in Proceedings of the 16th International Conference of Ethiopian Studies, vol. 3, pp. 711-726, Trondheim, Norway, 2009.

[69] G. Alemayehu, Z. Asfaw, and E. Kelbessa, "Plant diversity and ethnobotany in Berehet District, North Shewa Zone of Amhara Region (Ethiopia) with emphasis on wild edible plants," Journal of Medicinal Plants Studies, vol. 3, no. 6, pp. 93-105, 2015.

[70] T. Teklehaymanot and G. Mirutse, "Ethnobotanical study of wild edible plants of Kara and Kwego semi-pastoralist people in Lower Omo River Valley, Debub Omo Zone, SNNP, 
Ethiopia," Journal of Ethnobiology and Ethnomedicine, vol. 6, p. 13, 2010.

[71] M. Kebebew and G. Leta, "Wild edible plant bio-diversity and utilization system in Nech Sar National Park, Ethiopia," International Journal of Bio-resource and Stress Management, vol. 7, no. 4, pp. 885-896, 2016.

[72] T. Bahru, Z. Asfaw, and S. Demissew, "Wild edible plants: sustainable use and management by indigenous communities in and the buffer area of Awash National Park, Ethiopia," SINET: Ethiopian Journal of Science, vol. 36, no. 2, pp. 93-108, 2013.

[73] M. Meragiaw, Z. Asfaw, and M. Argaw, "Indigenous knowledge (IK) of wild edible plants (WEPs) and impacts of resettlement in Delanta, Northern Ethiopia," Research and Reviews: Journal of Herbal Sciences, vol. 5, no. 3, pp. 8-26, 2015.

[74] Food and Agriculture Organization of the United Nations, Integrated Food Security and Humanitarian Phase Classification (IPC) Framework, Food and Agriculture Organization, Rome, Italy, 2006.

[75] A. D. Dirres, "Collection and identification of wild fruits tree/shrub species in Amhara region, Ethiopia," Journal of Natural Sciences Research, vol. 6, no. 11, 2016.

[76] B. Anbessa, "Ethnobotanical study of wild edible plants in Bule Hora Woreda, Southern Ethiopia," African Journal of Basic \& Applied Sciences, vol. 8, no. 4, pp. 198-207, 2016.

[77] T. Berihun and E. Molla, "Study on the diversity and use of wild edible plants in Bullen District Northwest Ethiopia," Journal of Botany, vol. 2017, Article ID 8383468, 10 pages, 2017.

[78] Z. Asfaw and M. Tadesse, "Prospects for sustainable use and development of wild food plants in Ethiopia," Economic Botany, vol. 55, no. 1, pp. 47-62, 2001.

[79] E. Amenu, Use and management of medicinal plants by indigenous people of Ejaji area (Chelya Woreda) West Shoa, Ethiopia: an ethnobotanical approach, [M. S. thesis], Addis Ababa university school if Gradtuate studies, 2007.

[80] F. Mesfin, S. Demissew, and T. Teklehaymanot, "An ethnobotanical study of medicinal plants in Wonago Woreda, SNNPR, Ethiopia," Journal of Ethnobiology and Ethnomedicine, vol. 5, no. 1, p. 28, 2005.

[81] D. F. Guyu and W. T. Muluneh, "Wild foods (plants and animals) in the green famine belt of Ethiopia: do they contribute to household resilience to seasonal food insecurity?," Forest Ecosystems, vol. 2, no. 1, p. 34, 2015.

[82] D. Beche, G. Gebeyehu, and K. Feyisa, "Indigenous utilization and management of useful plants in and around Awash National Park, Ethiopia," Journal of Plant Biol Soil Health, vol. 3, no. 1, p. 12, 2016.

[83] M. Ashagre, Z. Asfaw, and E. Kelbessa, "Ethnobotanical study of wild edible plants in Burji District, Segan Area Zone of Southern Nations, Nationalities and Peoples' Region (SNNPR), Ethiopia," Journal of Ethnobiology and Ethnomedicine, vol. 12, no. 1, p. 32, 2016.

[84] M. Tebkew, Z. Asfaw, and S. Zewudie, "Underutilized wild edible plants in the Chilga District, northwestern Ethiopia: focus on wild woody plants," Agriculture \& Food Security, vol. 3, no. 1, p. 12, 2014.

[85] A. Pieroni, S. Nebel, R. F. Santoro, and M. Heinrich, "Food for two seasons: culinary uses of non-cultivated local vegetables and mushrooms in south Italian village," International Journal of Food Forestry, vol. 3, no. 2, pp. 32-41, 2005.

[86] G. Addis, Z. Asfaw, and Z. Woldu, "Ethnobotany of wild and semi-wild edible plants of Konso ethnic community, South
Ethiopia," Ethnobotany Research and Applications, vol. 11, pp. 121-141, 2013.

[87] A. Kebede, W. Tesfaye, M. Fentie, and H. Zewide, "An ethnobotanical survey of wild edible plants commercialized in Kefira Market, Dire Dawa City, eastern Ethiopia," Plant, vol. 5, no. 2, pp. 42-46, 2017.

[88] A. Ray, R. Ray, and E. A. Sreevidya, "How many wild edible plants do we eat - their diversity, use, and implications for sustainable food system: an exploratory analysis in India," Frontiers in Sustainable Food Systems, vol. 4, p. 56, 2020.

[89] F. Mazhar, D. Buckles, and P. V. Satheesh, Food Sovereignty and Uncultivated Biodiversity in South Asia: Essays on the Poverty of Food Policy and the Wealth of the Social Landscape, Academic Foundation, 2007.

[90] N. J. Turner, Ł. J. Łuczaj, P. Migliorini et al., "Edible and tended wild plants, traditional ecological knowledge and agroecology," Critical Reviews in Plant Sciences, vol. 30, no. 1-2, pp. 198-225, 2011.

[91] A. Ickowitz, B. Powell, D. Rowland, A. Jones, and T. C. H. Sunderland, "Agricultural intensification, dietary diversity, and markets in the global food security narrative," Global Food Security, vol. 20, pp. 9-16, 2019.

[92] M. Gebru, F. Odhiamo, G. Lochetti, G. Kennedy, and K. Baye, Ethiopia's food treasures: revitalizing Ethiopia's underutilized fruits and vegetables for inclusion in the Food-Based Dietary Guidelines for improved diet diversity, nutrition and health of the population, Bioversity International, Rome, Italy and Addis Ababa, Ethiopia, 2019.

[93] S. C. Ifejika, Resilient adaptation to climate change in African agriculture, Studies, 2010.

[94] T. Dejene, M. S. Agamy, D. Agúndez, and P. Martin-Pinto, "Ethnobotanical survey of wild edible fruit tree species in lowland areas of Ethiopia," Forests, vol. 11, no. 2, p. 177, 2020.

[95] T. Diress, B. Mulubrhan, G. H. Kindeya et al., The role of garsa (Dobera glabra) for household food security at times of food shortage in Abaàla Wereda, North Afar: ecological adaptation and socio-economic value, Dry Land Coordination Group (DCG), Addis Ababa, Ethiopia, 2007.

[96] M. A. Osman and M. A. Ahmed, "Chemical and proximate composition of (Zizyphus spina-christi) nabag fruit," Nutrition and Food Science, vol. 39, no. 1, pp. 70-75, 2009.

[97] C. Abuye, K. Urga, H. Knapp et al., “A compositional study of Moringa stenopetala leaves," East African Medical Journal, vol. 80, no. 5, pp. 247-252, 2003.

[98] M. Meragiaw, "Wild useful plants with emphasis on traditional use of medicinal and edible plants by the people of Aba'ala, North-eastern Ethiopia," Journal of Medicinal Plant and Herbal Therapy Research, vol. 4, pp. 1-16, 2016.

[99] G. A. Legesse, Plant diversity and ethnobotany of medicinal and wild edible plants in Amaro District of Southern Nations, Nationalities and Peoples Region and Gelana District of Oromia Region, Southern Ethiopia, [Ph.D. Thesis], Biology: Botanical Science, Addis Ababa University, Addis Ababa, Ethiopia, 2017. 